\title{
Arbuscular mycorrhizal and dark septate endophyte associations of medicinal plants
}

\author{
Szymon Zubek ${ }^{1 *}$, Janusz Błaszkowski², Piotr Mleczko ${ }^{1}$ \\ ${ }^{1}$ Institute of Botany, Jagiellonian University, Lubicz 46, 31-512 Kraków, Poland \\ ${ }^{2}$ Department of Plant Protection, West Pomeranian University of Technology, Słowackiego 17, 71-434 Szczecin, Poland
}

\section{Abstract}

Arbuscular mycorrhizal fungi (AMF) and dark septate endophyte (DSE) associations were studied in 36 medicinal plant species from 33 genera and 17 families, collected from the Botanical Garden of the Jagiellonian University in Kraków. Arbuscular mycorrhiza (AM) was found in 34 species (94\%); 26 were of the Arum-type, 4 - Paris and 4 taxa revealed intermediate morphology. The abundance of AMF hyphae in roots varied with particular species, ranging from 2.5\% (Helianthus tuberosus) to $77.9 \%$ (Convallaria majalis). The mycelium of DSE was observed in 13 plant species (36\%), however, the percentage of root colonization by these fungi was low. Spores of 7 AMF species (Glomeromycota) were isolated from trap cultures established from rhizosphere soils of the investigated plants: Archaeospora trappei (Archaeosporaceae), Glomus aureum, Glomus caledonium, Glomus claroideum, Glomus constrictum, Glomus mosseae, Glomus versiforme (Glomeraceae). Our results are the first detailed report of root endophyte associations of the plant species under study. Moreover, the mycorrhizal status of 14 plant species is reported for the first time.

Keywords: arbuscular mycorrhiza (AM), AM morphology, Arum-type, dark septate endophytes (DSE), Glomeromycota, mycorrhizal status, Paris-type

\section{Introduction}

Over 35000 medicinal plant species are used in medicine in different regions of the world [1]. To meet the increasing demand of plant material used in herbal industry, cropping of numerous species is presently carried out. In order to develop effective methods of biomass production and obtain high quality plant material, recent research emphasis is on exploring soil microorganisms beneficial for plant performance. Among them the most important are arbuscular mycorrhizal fungi (AMF) and dark septate endophytes (DSE). In several studies, AMF and DSE have been found to enhance plant growth, photosynthetic activity, phosphorus content, act antagonistically towards soilborne fungal pathogens, and modify the concentration of plant metabolites [2-17]. For this reason, the recognition of mycorrhizal status, monitoring of soil fungi and selection of beneficial microbial consortia to inoculate cultivated medicinal plants could be of particular value.

Poland is one of the leaders among European countries in the production of plant material for herbal industry [18-20].

*Corresponding author. Email: szymon.zubek@uj.edu.pl

This is an Open Access digital version of the article distributed under the terms of the Creative Commons Attribution 3.0 License (creativecommons.org/licenses/by/3.0/), which permits redistribution, commercial and non-commercial, provided that the article is properly cited.
Nevertheless, investigations on symbiotic microorganisms have been rarely conducted in Poland so far. First and, to our best knowledge, the only one study to date on the mycorrhizal status of medicinal plants conducted Zubek and Błaszkowski [21]. Furthermore, also few experimental studies concerning the influence of AMF on selected medicinal plant species have been carried out recently by Sawilska et al. [22], Jurkiewicz et al. [15], and Zubek et al. [16]. The aim of the present study was to examine the AMF diversity and the fungal root colonization of selected species, both introduced and native to the flora of Poland, from the collection of the Jagiellonian University Botanical Garden in Kraków. We focused on the evaluation of mycorrhizal status and the degree of AMF and DSE root colonization as well as the characterization of morphotypes of arbuscular mycorrhiza (AM) of these plant species. The research broadens the knowledge of ecology of the investigated plants.

\section{Material and methods}

\section{Sample collection}

The material was collected from the section of medicinal plants of the Jagiellonian University Botanical Garden in Kraków. The garden holds a collection of approximately 200 medicinal plant taxa (E. Nowotarska personal communication, 2010). The selection of plant species was done mainly on the basis of their presence in Polish Pharmacopoeia [23], the importance of species for herbal industry (based on the amount 
of plant raw material obtained in Poland for pharmaceutical purposes; [18]), and the legal status of taxa in Poland [24]. Moreover, the species of unknown mycorrhizal status and AM morphology were selected for investigations. Thirty six species were collected during the flowering and early seed formation period in June 2009 (see Tab. 1). In the case of each species, three samples were collected. Whole plants were excavated and cleaned mechanically from soil. Roots were washed in running tap water and then subjected to staining procedure. Rhizosphere soils were collected for the establishment of AMF trap cultures.

\section{Root staining and the assessment of fungal colonization}

Roots were prepared according to the modified Phillips and Hayman [25] method. Roots were cleared in $10 \% \mathrm{KOH}$ for 24 $\mathrm{h}$ and then rinsed in tap water. The material was then acidified in $5 \%$ lactic acid in water $(24 \mathrm{~h})$, stained with $0.05 \%$ aniline blue in $80 \%$ lactic acid $(48 \mathrm{~h}$ ), and finally stored in $80 \%$ lactic acid until analyzed. The whole procedure was performed at room temperature (approx. $22^{\circ} \mathrm{C}$ ). Root fragments (ca. $1 \mathrm{~cm}$ long; 15-30 fragments per sample) were mounted on slides in glycerol:lactic acid (5:1) and squashed using coverslides.

Fungal root colonization was assessed using Nikon Eclipse 80i light microscope with Nomarski interference contrast optics and a digital camera with a panel for image analysis. AMF colonization was identified on the basis of aseptate hyphae of irregular diameter, growing $(i)$ intercellularly, forming arbuscules terminally in cortical cells (Arum-type of AM morphology), (ii) intracellularly with arbuscules developed on coils in cortical cells (Paris-type) or (iii) forming intermediate types [26-28]. Fine endophyte [usually considered Glomus tenue (Greenall) I.R. Hall [26,29]] AM-type colonization was counted separately from coarse AM-type colonization. The fine endophyte was identified on the basis of the following characteristics: mycelium ca. $1 \mu \mathrm{m}$ in diameter, deep blue stained hyphae, the presence of small vesicles or swellings and fan-shaped branches [21,26,30,31]. The method proposed by Trouvelot et al. [32] was followed for the assessment of AM development. The parameters evaluated were: mycorrhizal frequency $(F)$, relative mycorrhizal root length $(M)$, and relative arbuscular richness $(A)$. An estimate of mycorrhizal frequency $(F \%)$ is given as the ratio between root fragments colonized by AMF mycelium and the total number of root fragments analysed. The relative mycorrhizal root length $(M \%)$ is an estimate of the amount of root cortex that is mycorrhizal relative to the whole root system. Arbuscule abundance $(A \%)$ is an estimate of arbuscule richness in the whole root system [32]. DSE colonization was identified on the basis of regularly septate hyphae, usually dark pigmented, with facultatively occurring sclerotia $[21,30,31,33,34]$. In the case of DSE colonization, the frequency of DSE mycelium occurrence in roots $\left(F_{\mathrm{DSE}} \%\right)$ was estimated as detailed above for AMF. Additionally, the frequency of occurrence of resting spores of fungi from the genus Olpidium $\left(F_{\text {Olp }} \%\right)$ was assessed $[21,30]$.

\section{Establishment of AMF trap cultures}

Soil samples were excavated from the rhizosphere of all investigated plant species. In the case of each species, three subsamples were collected and mixed together. For the trap culture establishment, the soils with root fragments (ca. $100 \mathrm{~g}$ of fresh soil) were placed into $9 \times 12.5 \mathrm{~cm}$ plastic pots $(500 \mathrm{ml})$ containing autoclaved commercially available coarse-grained sand (grains 1.0-10.0 mm in diam. - 80.50\%; grains 0.1-1.0 $\mathrm{mm}$ in diam. - 17.28\%; grains $<0.1 \mathrm{~mm}$ in diam. $-2.22 \%$ ). Plantago lanceolata L. was used as host plant. On the whole, 36 trap cultures were established. The cultures are maintained under greenhouse conditions in the AMF collection of the West Pomeranian University of Technology, Szczecin.

\section{AMF spores extraction and identification}

Seven months after the establishment of trap cultures, AMF spores were extracted using wet sieving and decanting method [35]. Morphological properties of spores and their subcellular structures were determined in material mounted in a drop of polyvinyl alcohol/lactic acid/glycerol (PVLG) and in a mixture of PVLG/Melzer's reagent $(4: 1, \mathrm{v} / \mathrm{v})$ on a slide [36]. Identification of AMF spores was performed using Olympus BX51 light microscope. Fungal species names were after Walker and Trappe [37]. The slides with isolated spores were deposited in the slide collection of the Department of Plant Protection, West Pomeranian University of Technology, Szczecin.

\section{Determination of soil characteristics}

For soil chemical analyses (Tab. 2), five soil samples excavated at the site were mixed and analysed as bulk sample. The total phosphorus content was determined in ammonium lactate extraction according to the Egner-Rim method, total nitrogen by the Kjeldahl method, and total carbon by the Tiurin method [38,39].

\section{Results}

\section{AM status and morphology}

Arbuscular mycorrhizae with arbuscules, which are the structural and functional criterion of the symbiosis, were found in 34 out of 36 investigated plant species (94\%). AM structures were not found in the roots of Glycine max and Veronica urticifolia. The abundance of arbuscular mycorrhizal fungi (AMF) in roots varied with particular species, ranging from $2.5 \%$ (Helianthus tuberosus) to $77.9 \%$ (Convallaria majalis; Tab. 1). In roots of all mycorrhizal plants coarse AMF (hyphae diameter above $2 \mu \mathrm{m}$ ) dominated (Fig. 1). The fine AM endophyte (Glomus tenue; Fig. 1) was found sporadically in 2 plant species (5.9\%) - Pimpinella anisum and Verbena officinalis, and was observed to form arbuscules only in P. anisum (Tab. 1).

The AM of 26 plant species was of the Arum morphology (Tab. 1). Hyphae were observed mainly in the intercellular spaces of root cortex, forming arbuscules terminally in cortical cells (Fig. 1). Four species were characterized by Paris-type colonization in which neighbouring cortical cells contained hyphal coils, without hyphae in the intercellular spaces (Fig. 1). The intermediate AM colonization was found in 4 plant species from Apiaceae family (Tab. 1).

\section{DSE colonization}

DSE were found in 13 plant species (36\%; Tab. 1). The single hyphae, accompanied sporadically by sclerotia (Fig. 1), were found in rhizodermis and outer cortical cells. The mycelium was brownish or stained with aniline blue. Single DSE hyphae were also detected on the root surface. In the old roots of several species, which were not included in the assessments of AMF and DSE colonization, DSE mycelium was abundant. 
Tab. 1 Arbuscular mycorrhizal (AM) and dark septate endophyte (DSE) associations of medicinal plant species collected from the Botanical Garden of the Jagiellonian University.

\begin{tabular}{|c|c|c|c|c|c|c|c|c|c|c|c|}
\hline \multirow[b]{2}{*}{ Family } & \multirow[b]{2}{*}{ Plant species $^{\mathrm{a}}$} & \multirow[b]{2}{*}{$\begin{array}{l}\text { Medicinal } \\
\text { use }^{\mathrm{b}}\end{array}$} & \multirow{2}{*}{$\begin{array}{c}\text { AM } \\
\text { literature } \\
\text { status }^{\mathrm{c}}\end{array}$} & \multirow[b]{2}{*}{ AM type ${ }^{d}$} & \multicolumn{4}{|c|}{ Coarse AMF $^{e}$} & \multicolumn{3}{|c|}{ Other endophytes } \\
\hline & & & & & $F$ & $M$ & $A$ & $F_{\mathrm{V}}$ & $F_{\mathrm{FE}}$ & $F_{\mathrm{DSE}}$ & $F_{\text {Olp }}$ \\
\hline Acanthaceae & Acanthus longifolius Host non Poir. $(=\text { A. mollis })^{1}$ & & NS & A & 97.8 & 51.9 & 36.6 & 14.1 & - & - & - \\
\hline \multirow[t]{5}{*}{ Apiaceae } & Conium maculatum $\mathrm{L}^{7}$ & & $1+$ & $\mathrm{I} 3, \mathrm{I} 4$ & 88.1 & 29.8 & 23.3 & 9.7 & - & 32.9 & - \\
\hline & Levisticum officinale W.D.J. Koch ${ }^{15}$ & PP, 2 & NS & $\mathrm{I} 1, \mathrm{I} 3, \mathrm{I} 4$ & 95.0 & 56.0 & 44.5 & - & - & 5.0 & 5.0 \\
\hline & Peucedanum ostruthium (L.) W.D.J. Koch ${ }^{36}$ & & $1+$ & $\mathrm{P}$ & 98.0 & 56.6 & 56.3 & - & - & 2.0 & - \\
\hline & Pimpinella anisum $\mathrm{L}^{19}$ & PP & NS & $\mathrm{I} 3, \mathrm{I} 4$ & 87.7 & 30.3 & 24.4 & 16.7 & 59.8 & 23.3 & 1.8 \\
\hline & Pimpinella major (L.) Huds..$^{20}$ & & $1+/-$ & $\mathrm{I} 3, \mathrm{I} 4$ & 89.3 & 17.8 & 21.1 & - & - & 10.7 & 24.1 \\
\hline Apocynaceae & Vinca minor $\mathrm{L}^{27}$ & p-prot. & $1+$ & A & 95.2 & 64.2 & 41.3 & 55.6 & - & - & - \\
\hline Asclepiadaceae & Vincetoxicum hirundinaria Medik. $(=\text { V. officinale })^{35}$ & & $2+$ & A & 68.4 & 12.5 & 9.0 & - & - & - & - \\
\hline \multirow[t]{7}{*}{ Asteraceae } & Achillea millefolium L. s.str. ${ }^{2}$ & PP, 1 & $1+/-, 3+$ & A & 71.0 & 37.3 & 23.2 & 2.1 & - & - & 31.8 \\
\hline & Arnica chamissonis Less. ${ }^{6}$ & & NS & A & 88.0 & 61.3 & 46.1 & 4.8 & - & - & - \\
\hline & Grindelia robusta Nutt. ${ }^{13}$ & & NS & A & 96.0 & 53.9 & 42.2 & 4.8 & - & - & - \\
\hline & Helianthus tuberosus L. $^{5}$ & & NS & A & 17.5 & 2.5 & 1.0 & 2.2 & - & - & 33.7 \\
\hline & Tanacetum parthenium (L.) Sch. Bip. ${ }^{28}$ & & $1-$ & A & 68.4 & 20.2 & 14.4 & - & - & - & 3.8 \\
\hline & Taraxacum officinale F.H. Wigg. ${ }^{29}$ & 1 & $1+$ & A & 75.5 & 19.6 & 13.2 & - & - & - & 15.9 \\
\hline & Tussilago farfara $\mathrm{L}^{31}$ & 1 & $1+/-$ & A & 51.2 & 14.1 & 11.9 & - & - & - & 45.5 \\
\hline Boraginaceae & Anchusa officinalis $\mathrm{L}^{4}{ }^{4}$ & & NS & A & 25 & 8.4 & 4.2 & - & - & - & 25.0 \\
\hline Convallariaceae & Convallaria majalis $\mathrm{L}^{8}$ & p-prot., 3 & $1+/-$ & A & 95.4 & 77.9 & 69.4 & 65.1 & - & - & - \\
\hline Fabaceae & Glycine $\max (\mathrm{L}$.$) Merr. { }^{11}$ & $\mathrm{PP}$ & $1+$ & $\mathrm{NM}$ & - & - & - & - & - & - & 13.3 \\
\hline \multirow[t]{6}{*}{ Lamiaceae } & Prunella vulgaris $\mathrm{L} .^{23}$ & & $1+/-, 3+$ & A & 88.8 & 53.6 & 44.3 & - & - & - & - \\
\hline & Salvia sclarea $\mathrm{L}^{24}$ & $\mathrm{PP}$ & NS & A & 69.6 & 19.2 & 18.6 & 2.8 & - & - & 10.3 \\
\hline & Salvia verticillata $\mathrm{L} .{ }^{25}$ & & NS & A & 63.8 & 14.1 & 9.3 & 2.2 & - & - & 2.2 \\
\hline & Teucrium botrys $\mathrm{L} .^{10}$ & & NS & A & 97.6 & 58.7 & 47.1 & 4.7 & - & 6.8 & 22.6 \\
\hline & Teucrium chamaedrys L. ${ }^{14}$ & & $1+$ & A & 90.9 & 46.4 & 29.9 & - & - & - & 8.8 \\
\hline & Thymus serphyllum L. emend. Fr. ${ }^{30}$ & & $1+$ & $\mathrm{A}$ & 86.4 & 38.0 & 37.1 & - & - & - & - \\
\hline Linaceae & Linum usitatissimum $\mathrm{L}^{16}$ & PP & $1+/-$ & $\mathrm{A}, \mathrm{A} 1$ & 13.3 & 4.7 & 4.5 & - & - & - & 8.0 \\
\hline Papaveraceae & Papaver rhoeas L. ${ }^{18}$ & $\mathrm{PP}$ & $1+/-$ & $\mathrm{P}$ & 74.4 & 57.8 & 57.8 & - & - & - & 23.3 \\
\hline Plantaginaceae & Plantago major L. s.str. ${ }^{32}$ & & $1+$ & A & 89.0 & 57.7 & 40.8 & - & - & - & 11.0 \\
\hline Primulaceae & Primula veris $\mathrm{L} .(=P . \text { officinalis })^{22}$ & PP, p-prot. & $1+/-$ & $\mathrm{P}$ & 33.2 & 16.5 & 16.0 & - & - & 2.4 & - \\
\hline \multirow[t]{3}{*}{ Rosaceae } & Agrimonia eupatoria L. $^{3}$ & $\mathrm{PP}$ & $1+$ & A & 87.5 & 43.7 & 29.5 & 27.8 & - & 47.7 & - \\
\hline & Potentilla erecta (L.) Raeusch. ${ }^{21}$ & $\mathrm{PP}$ & $1+/-$ & A & 100 & 47.1 & 33.2 & 24.1 & - & - & 3.7 \\
\hline & Sanguisorba officinalis L. ${ }^{26}$ & $\mathrm{PP}$ & $1+$ & A & 91.3 & 36.3 & 18.4 & 8.3 & - & 4.8 & 28.3 \\
\hline \multirow[t]{3}{*}{ Scrophulariaceae } & Digitalis lutea $\mathrm{L}^{9}{ }^{9}$ & & NS & A & 94.5 & 41.0 & 37.4 & - & - & 18.1 & 32.0 \\
\hline & Gratiola officinalis $\mathrm{L} .{ }^{12}$ & prot. & NS & A & 80.3 & 49.8 & 43.1 & - & - & - & - \\
\hline & Veronica urticifolia Jacq. $(=\text { V. latifolia })^{34}$ & & NS & NM & - & - & - & - & - & 5.0 & 3.3 \\
\hline Solanaceae & Physalis alkekengi $\mathrm{L}^{17}$ & & NS & $\mathrm{P}$ & 92.4 & 71.4 & 70.4 & 42.9 & - & 18.3 & 22.0 \\
\hline Verbenaceae & Verbena officinalis $\mathrm{L}^{33}$ & PP & $1+$ & A & 100 & 72.2 & 38.5 & 16.8 & 3.5 & 5.5 & 32.8 \\
\hline
\end{tabular}

a Plant species names according to Mirek et al. [60] except for Arnica chamissonis and Salvia sclarea which followed Anioł-Kwiatkowska [61]. Numbers after plant species names indicate collection sample number and trap culture number (see also Tab. 3). ${ }^{\mathrm{b}}$ Medicinal use and other information concerning plant species; PP indicates that the plant species is included in the 8th edition of Polish Pharmacopoeia [23]. Numbers (1-3) indicate the amount of plant raw material obtained per year in Poland for herbal industry (based on data from the years 1995-1999), after Jambor [18]. 1 - 50-100 tons; 2 - 10-50 tons; 3 - 5-10 tons. The legal status of the taxon in Poland after Piękoś-Mirkowa and Mirek [24]. prot. - protected plant species; p-prot. - species partially protected. ${ }^{\mathrm{c}} \mathrm{AM}$ status according to available literature. The presented information is based mainly on the checklist by Wang and Qiu [40] and is updated with the data published thereafter: 1 - [40], 2 - [53], 3 - [62]. “+” - AM present; “-” - AM absent; NS - not surveyed. ' AM status and morphotype (according to Dickson [27]) observed in this study. A - Arum type; A1 - Arum type with paired arbuscules in adjacent cells; P - Paris type; I - intermediate types: I1 - intercellular hyphae with terminally formed arbuscules in inner cortex and intracellular hyphae in outer cells; I3 - intracellular hyphae with arbuscules and intercellular hyphae; I4 - intracellular hyphal coils, intracellular arbusculate coils and intercellular hyphae. NM - nonmycorrhizal. ${ }^{\mathrm{e}}$ Coarse AMF; mycorrhizal parameters (\%; mean, $n=3$ ). $A$ - relative arbuscular richness; $F$ - mycorrhizal frequency; $F_{\mathrm{V}}$ - frequency of the occurrence of vesicles; $M$ relative mycorrhizal root length. ${ }^{\mathrm{f}}$ Frequency of the occurrence of other endophytes (\%; mean, $n=3$ ). $F_{\mathrm{FE}}-$ fine AM endophyte (Glomus tenue) mycelium; $F_{\mathrm{DSE}}-$ mycelium of dark septate endophytes; $F_{\mathrm{Olp}}$ - resting spores of Olpidium spp. 


\section{Other fungal endophytes}

The resting spores of Olpidium spp. (Fig. 1), which were stained with aniline blue, were found in 23 plant species. The frequency of occurrence of these structures varied from 1.8 to $45.5 \%$ (Tab. 1). The percentage of root infection was low (data not shown); the single resting spores were found in rhizodermis and outer cortex.

\section{AMF diversity}

Spores of 7 AMF species from 2 families were isolated from the 36 trap cultures established from the rhizosphere soils collected in the garden: Archaeospora trappei (R. N. Ames \& Linderman) J. B. Morton \& D. Redecker emend. Spain (Archaeosporaceae), Glomus aureum Oehl \& Sieverd., Glomus caledonium (T. H. Nicolson \& Gerd.) Trappe \& Gerd., Glomus claroideum N. C. Schenck \& S. M. Sm., Glomus constrictum Trappe, Glomus mosseae (T. H. Nicolson \& Gerd.) Gerd. \& Trappe, and Glomus versiforme (P. Karsten) S. M. Berch. (Glomeraceae). AMF spores were found in all examined trap cultures. The fungi most frequently found were G. claroideum and G. mosseae, which were isolated from 27 and 24 cultures, respectively. These species usually sporulated abundantly in the cultures (Tab. 3). In contrast, G. aureum and G. versiforme were detected only in single cultures. Additionally, one unidentified Glomus species (spore morphotype) was isolated (Tab. 3).

Tab. 2 The chemical properties of soil collected from the section of medicinal plants of the Jagiellonian University Botanical Garden (see "Material and methods").

\begin{tabular}{cccccccccc} 
& & & & \multicolumn{4}{c}{ Total content } \\
$\mathbf{p H}$ & & & & & \multicolumn{4}{c}{$\begin{array}{c}\text { Organic } \\
\mathbf{m g ~ 1 0 0} \mathbf{g}^{-1}\end{array}$ of dry soil } \\
\cline { 7 - 10 }$\left(\mathbf{H}_{2} \mathbf{O}\right)$ & $\mathbf{N}(\%)$ & $\mathbf{C}(\%)$ & matter \% & $\mathbf{C} / \mathbf{N}$ & & $\mathbf{K}_{2} \mathbf{O}$ & $\mathbf{P}_{2} \mathbf{O}_{5}$ & $\mathbf{M g O}$ & $\mathbf{C a O}$ \\
\hline 7.1 & 0.2 & 2.9 & 5.1 & 12.3 & 18.8 & 45.0 & 31.0 & 761.6 \\
\hline
\end{tabular}

\section{Discussion}

In this paper, we present the detailed report of both AMF and DSE association of 34 medicinal plant species. The mycorrhizal status of 14 plant species is reported, to our best knowledge, for the first time (see Tab. 1). The presence of AM in 11 plant species was confirmed, consistent with previous literature data. Nine plant species were recognized in our studies as colonized by AMF, being reported earlier as either mycorrhizal or devoid of AMF. Tanacetum parthenium was found to form AM, whereas in earlier research was observed to be nonmycorrhizal [40]. Our investigations add data to the knowledge of mycorrhizal status and ecology of medicinal plant species. Furthermore, as it was recognized for rare and endangered plants, studies on mycorrhizal associations may also be important in the context of further investigations, regarding ecological restoration, preservation and propagation [30,41-45]. It could be crucial in the case of four species investigated in our research that are under legal protection in Poland (see Tab. 1). There is also the aforementioned possibility of AMF application in the cropping system of several investigated species in order to improve biomass production and the quality of plant material obtained for herbal industry $[5,6,8,10,12,13,16,21,46]$. In such attempts, basic studies, like a mycorrhizal status survey, are considered as a prerequisite for further investigations $[21,46]$.

We found AMF spores in all trap cultures, even the ones established from the rhizosphere soils of Glycine max and Veronica urticifolia, which were found to be nonmycorrhizal in our studies. As AMF, in general, are believed to colonize roots of a wide range of plants [28], the lack of functional need for mycorrhizal association in these particular edaphic conditions seems to be the reason for the absence (G. max and V. urticifolia) or low (Anchusa officinalis, Helianthus tuberosus, Linum usitatissimum) AM colonization of these species rather than the absence of AMF propagules in the soil. Nevertheless, there is increasing evidence for some degree of physical and functional specificity in the symbiosis [28,47-49]. Therefore, if some AMF are required for particular plant species, the lack of compatibile fungal symbionts may be the reason for the lack or lower root colonization. Furthermore, G. max was found to be mycorrhizal in earlier studies [40], which seems to support

Tab. 3 Species of arbuscular mycorrhizal fungi (Glomeromycota) isolated from trap cultures established from rhizosphere soils of the investigated medicinal plant species.

Frequency of spore occurrence in trap cultures ${ }^{\mathrm{a}}$

Fungal species

$\begin{array}{llllllllllllllllllllllllllllllllllll}1 & 2 & 3 & 4 & 5 & 6 & 7 & 8 & 9 & 10 & 11 & 12 & 13 & 14 & 15 & 16 & 17 & 18 & 19 & 20 & 21 & 22 & 23 & 24 & 25 & 26 & 27 & 28 & 29 & 30 & 31 & 32 & 33 & 34 & 35 & 36\end{array}$

Archaeospora trappei

Glomus aureum

Glomus caledonium

Glomus claroideum

Glomus constrictum

Glomus mosseae

Glomus versiforme
Glomus sp. 178

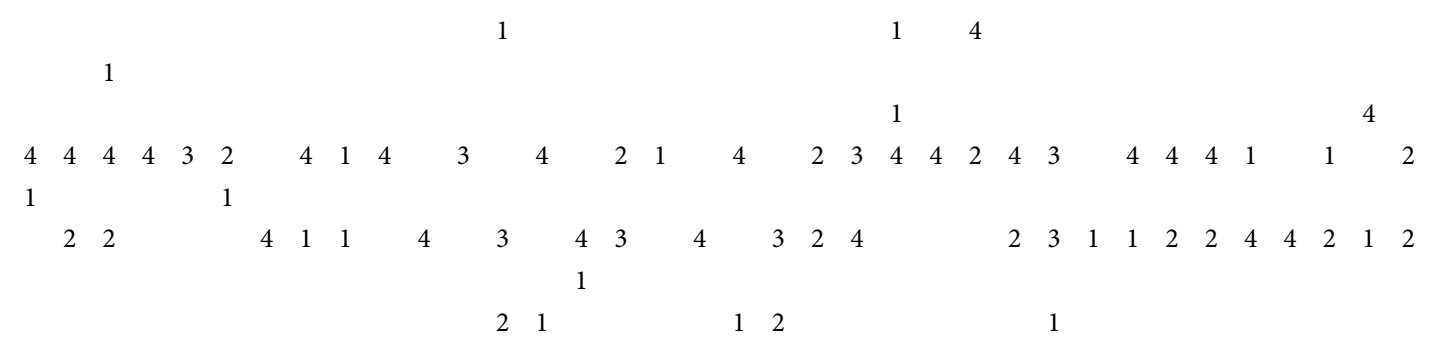

a Numbers from 1 to 36 indicate plant numbers and trap culture numbers (see Tab. 1) from which the fungal species were isolated. The numbers 1-4 indicate the frequency of spore occurrence of particular species in the trap cultures. 4 - spores most frequently isolated; 1 - spores least frequently isolated. 


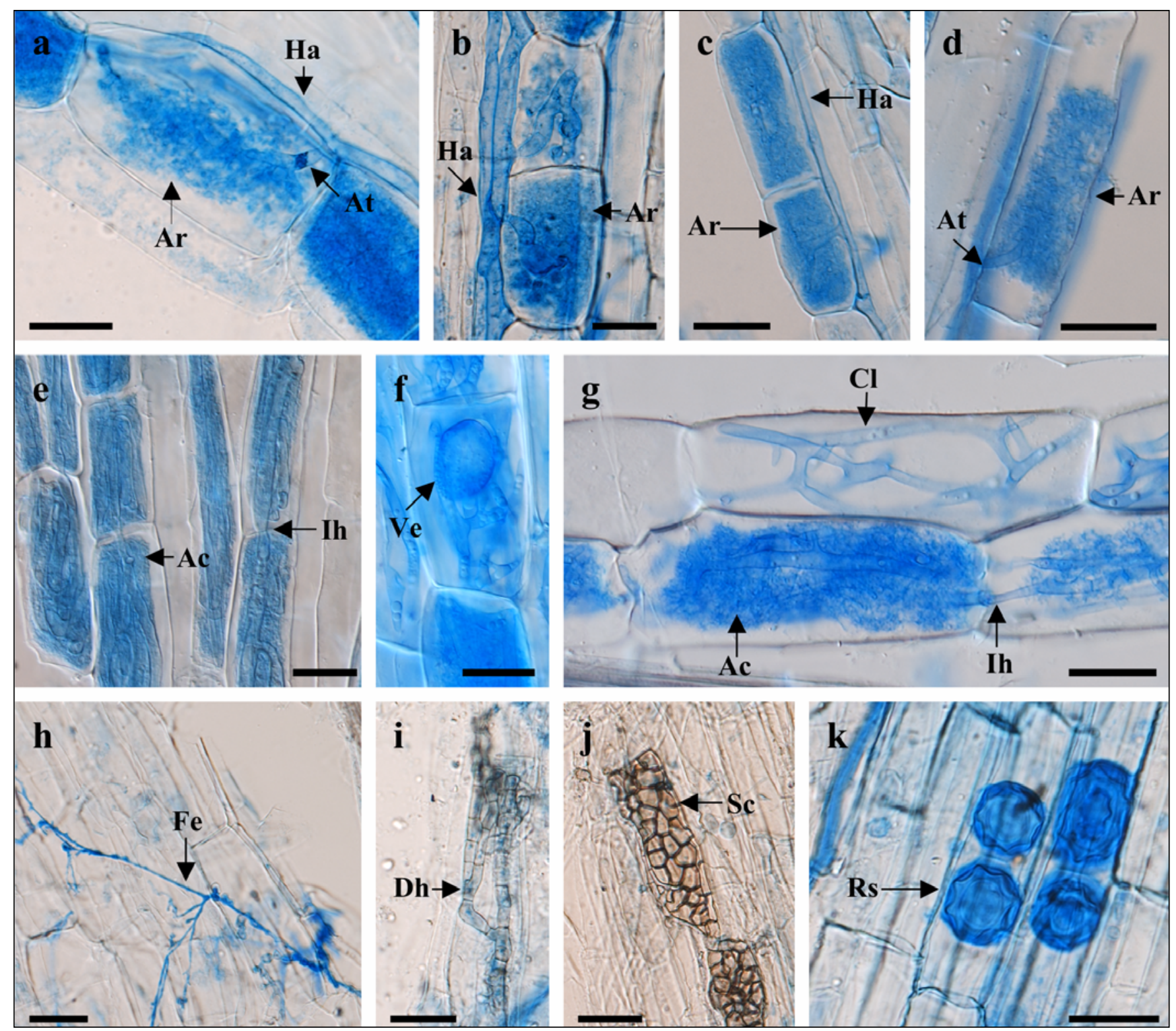

Fig. 1 a-k Endophytes in the roots of investigated medicinal plant species (Nomarski interference contrast optics). a-d Coarse AMF mycelium in the cortex of a Arnica chamissonis; b Grindelia robusta; c Prunella vulgaris; d Gratiola officinalis (Arum-type). e-g Paris-type of AM in e Primula veris and $\mathbf{f}, \mathbf{g}$ Physalis alkekengi. h Fine endophyte (Glomus tenue) mycelium (Arum-type) in the root cortex of Pimpinella anisum. $\mathbf{i}, \mathbf{j}$ DSE hyphae and sclerotium in the outer cortex of Pimpinella anisum root. k Resting spores of Olpidium sp. in the rhizodermis of Helianthus tuberosus. Ac - arbuscules formed on coils; Ar - terminally formed arbuscules; At - arbuscule trunks; Cl - coils; Dh - DSE hyphae; Fe - fine endophyte mycelium; Ha - hyphae growing intercellularly; Ih - coarse AMF hyphae growing intracellularly from cell to cell; Rs - resting spores; Sc - sclerotium; Ve - vesicle formed inside a cortical cell. Scale bars: $25 \mu \mathrm{m}$.

both of these possibilities.

It is widely recognized that plant species differ in the pattern of AMF root colonization. Host plants have main control over AM morphology, however, a fungal identity and different environmental factors may also have an impact on the structural classes of AM [27,28,50-53]. In our investigation, 26 plant species representing Acanthaceae, Apocynaceae, Asteraceae, Boraginaceae, Convallariaceae, Lamiaceae, Linaceae, Plantaginaceae, Rosaceae, and Scrophulariaceae showed Arum-type. The results are in accordance with other studies concerning AM morphology, where exclusively or mostly Arum-type was detected in these families. However, also Paris and intermediate patterns of AM colonization were observed in our survey. It confirms earlier observations where Paris, intermediate and Arum colonization was found among different species belonging to Apiaceae, Asclepiadaceae, Primulaceae, Solanaceae, and
Verbenaceae $[11,21,30,44,53,54]$.

In the case of Achillea millefolium, Convallaria majalis, Plantago major, Primula veris, Taraxacum officinale, Vinca minor, and Vincetoxicum hirundinaria, the morphotypes found in the present study were consistent with previous observations [53]. Linum usitatissimum was found to form typical and paired arbuscules of Arum-type, whereas previous investigations reported intermediate, Paris pattern or paired arbuscules of Arum-type in this species $[53,55]$. To our best knowledge, the AM morphology is characterized for the first time in the case of all other studied species and for Papaveraceae family.

Spores of 7 AMF species were identified in the trap cultures. Except for G. aureum, the other species have been frequently isolated from different soils and have a worldwide distribution [56]. Some of fungal isolates are maintained in the cultures and may serve as an inoculum source for the aforementioned 
experiments concerning plant-fungus interactions. Moreover, one unidentified Glomus species (spore morphotype) was found in the cultures. However, on the basis of the material isolated so far, the exact identification was not possible. Extraction and identification of spores further multiplied in the trap cultures may enable taxonomical classification of this isolate.

Dark septate endophytes (DSE) were rarely found in roots of the investigated medicinal plant species. DSE represent a taxonomically and ecologically diverse group of fungi. Their interactions with plants range from parasitic to symbiotic, depending on fungal species, host plants and environmental conditions [33]. Some strains were found to be beneficial to plant performance [14,17,57-59]. For example, in the studies by Zijlstra et al. [58] on Deschampsia flexuosa L., three DSE isolates were reported to enhance the shoot nitrogen content of seedlings. DSE were also found to colonize roots of Chinese medicinal plant - Saussurea involucrata Kar. et Kir. ex Maxim. The authors inoculated S. involucrata and the species displayed enhanced performance when the individuals were colonized by DSE [14,17]. Wu and Guo [14] proposed a biotechnological application of DSE in the future cropping system of S. involucrata. Similarly to AMF, DSE may play an important role in improving plant performance, especially in the case of taxa which are rarely or not colonized by AMF. The mechanism of interaction between DSE and their hosts is complex, thus experimental research to reveal the impact of this group of fungi on the plants investigated in our studies is necessary.

\section{Acknowledgements}

We are grateful to Prof. B. Zemanek and M.Sc. E. Nowotarska (Botanical Garden, Jagiellonian University, Kraków) for the permission for plant collection. M.Sc. eng. Barbara Szczepanowicz (Institute of Botany, Jagiellonian University) is acknowledged for her help with soil analysis. The present research was financially supported by Polish Ministry of Science and Higher Education, project No. N N304 381939 (2010-2013).

\section{References}

1. Kozłowski J, Buchwald W, Forycka A, Szczygielska D. Rośliny i surowce lecznicze. Poznań: Institute of Natural Fibres and Medicinal Plants; 2009.

2. Nemec S, Lund E. Leaf volatiles of mycorrhizal and nonmycorrhizal Citrus jambhiri Lush. J Essent Oil Res. 1990;2:287-297.

3. Abu-Zeyad R, Khan AG, Khoo C. Occurrence of arbuscular mycorrhiza in Castanospermum australe A. Cunn. $\&$ C. Fraser and effects on growth and production of castanospermine. Mycorrhiza. 1999;9:111-117. http://dx.doi. org/10.1007/s005720050008

4. Fester T, Maier W, Strack D. Accumulation of secondary compounds in barley and wheat roots in response to inoculation with an arbuscular mycorrhizal fungus and co-inoculation with rhizosphere bacteria. Mycorrhiza. 1999;8:241-246. http://dx.doi.org/10.1007/s005720050240

5. Kapoor R, Giri B, Mukerji KG. Glomus macrocarpum: a potential bioinoculant to improve essential oil quality and concentration in Dill (Anethum graveolens L.) and Carum [Trachyspermum ammi (Linn.) Sprague]. World J Microbiol Biotechnol. 2002;18(5):459-463. http://dx.doi.
org/10.1023/A:1015522100497

6. Kapoor R, Giri B, Mukerji KG. Mycorrhization of coriander (Coriandrum sativum $\mathrm{L}$ ) to enhance the concentration and quality of essential oil. J Sci Food Agric. 2002;82(4):339342. http://dx.doi.org/10.1002/jsfa.1039

7. Rojas-Andrade R, Cerda-García-Rojas C, Frías-Hernández J, Dendooven L, Olalde-Portugal V, Ramos-Valdivia A. Changes in the concentration of trigonelline in a semi-arid leguminous plant (Prosopis laevigata) induced by an arbuscular mycorrhizal fungus during the presymbiotic phase. Mycorrhiza. 2003;13:49-52. http://dx.doi.org/10.1007/ s00572-002-0201-X

8. Copetta A, Lingua G, Berta G. Effects of three AM fungi on growth, distribution of glandular hairs, and essential oil production in Ocimum basilicum L. var. Genovese. Mycorrhiza. 2006;16(7):485-494. http://dx.doi.org/10.1007/ s00572-006-0065-6

9. Khaosaad T, Vierheilig H, Nell M, Zitterl-Eglseer K, Novak J. Arbuscular mycorrhiza alter the concentration of essential oils in oregano (Origanum sp., Lamiaceae). Mycorrhiza. 2006;16(6):443-446. http://dx.doi.org/10.1007/ s00572-006-0062-9

10. Kapoor R, Chaudhary V, Bhatnagar AK. Effects of arbuscular mycorrhiza and phosphorus application on artemisinin concentration in Artemisia annua L. Mycorrhiza. 2007;17:581-587. http://dx.doi.org/10.1007/ s00572-007-0135-4

11. Muthukumar T, Senthilkumar M, Rajangam M, Udaiyan K. Arbuscular mycorrhizal morphology and dark septate fungal associations in medicinal and aromatic plants of Western Ghats, Southern India. Mycorrhiza. 2006;17(1):1124. http://dx.doi.org/10.1007/s00572-006-0077-2

12. Toussaint J-P. Investigating physiological changes in the aerial parts of AM plants: what do we know and where should we be heading? Mycorrhiza. 2007;17:349-353. http://dx.doi.org/10.1007/s00572-007-0133-6

13. Toussaint J-P, Smith FA, Smith SE. Arbuscular mycorrhizal fungi can induce the production of phytochemicals in sweet basil irrespective of phosphorus nutrition. Mycorrhiza. 2007;17:291-297. http://dx.doi.org/10.1007/ s00572-006-0104-3

14. Wu L, Guo S. Interaction between an isolate of darkseptate fungi and its host plant Saussurea involucrata. Mycorrhiza. 2008;18:79-85. http://dx.doi.org/10.1007/ s00572-007-0159-9

15. Jurkiewicz A, Ryszka P, Anielska T, Waligórski P, Białońska $\mathrm{D}$, Góralska K, et al. Optimization of culture conditions of Arnica montana L.: effects of mycorrhizal fungi and competing plants. Mycorrhiza. 2010;20:293-306. http://dx.doi. org/10.1007/s00572-009-0280-Z

16. Zubek S, Stojakowska A, Anielska T, Turnau K. Arbuscular mycorrhizal fungi alter thymol derivative contents of Inula ensifolia L. Mycorrhiza. 2010;20:497-504. http://dx.doi. org/10.1007/s00572-010-0306-6

17. Wu L, Lv Y, Meng Z, Chen J, Guo S-X. The promoting role of an isolate of dark-septate fungus on its host plant Saussurea involucrata Kar. et Kir. Mycorrhiza. 2010;20:127-135. http://dx.doi.org/10.1007/s00572-009-0268-8

18. Jambor J. Kierunki rozwoju krajowego rynku surowców i przetworów zielarskich. Wiad Ziel. 2001;10:1-7.

19. Seidler-Łożykowska K, Kucharski WA, Mordalski R. Ekologiczna uprawa roślin zielarskich. Radom: Centrum Doradztwa Rolniczego; 2005. 
20. Pisulewska E, Janeczko Z. Krajowe rośliny olejkowe: występowanie, uprawa, skład chemiczny, zastosowanie. Kraków: Know-How Piotr Kaczmarczyk; 2008.

21. Zubek S, Błaszkowski J. Medicinal plants as hosts of arbuscular mycorrhizal fungi and dark septate endophytes. Phytochem Rev. 2009;8:571-580. http://dx.doi.org/10.1007/ s11101-009-9135-7

22. Sawilska AK, Jendrzejczak E, Welc M, Kieliszewska-Rokicka B. Influence of mycorrhizal fungi on the growth and development of sandy everlasting Helichrysum arenarium (L.) Moench. Acta Agrobot. 2009;62:67-76.

23. Polish Pharmacopoeia. 8th ed. Warszawa: Polish Pharmaceutical Society; 2008.

24. Piękoś-Mirkowa H, Mirek Z. Atlas roślin chronionych. Warszawa: Multico Oficyna Wydawnicza; 2003. (Flora Polski).

25. Phillips J, Hayman DS. Improved procedures for clearing roots and staining parasitic and vesicular-arbuscular mycorrhizal fungi for rapid assessment of infection. Trans Br Mycol Soc. 1970;55:158-161. http://dx.doi.org/10.1016/ S0007-1536(70)80110-3

26. Dodd JC, Boddington CL, Rodriguez A, Gonzalez-Chavez C, Mansur I. Mycelium of arbuscular mycorrhizal fungi (AMF) from different genera: form, function and detection. Plant Soil. 2000;226(2):131-151. http://dx.doi. org/10.1023/A:1026574828169

27. Dickson S. The Arum-Paris continuum of mycorrhizal symbioses. New Phytol. 2004;163(1):187-200. http://dx.doi.org/10.1111/j.1469-8137.2004.01095.x

28. Smith SE, Read DJ. Mycorrhizal symbiosis. 3rd ed. Amsterdam: Academic Press; 2008.

29. Thippayarugs S, Bansal M, Abbott LK. Morphology and infectivity of fine endophyte in a Mediterranean environment. Mycol Res. 1999;103(11):1369-1379. http://dx.doi. org/10.1017/S0953756299001094

30. Zubek S, Turnau K, Błaszkowski J. Arbuscular mycorrhiza of endemic and endangered plants from the Tatra Mts. Acta Soc Bot Pol. 2008;77:149-156.

31. Zubek S, Błaszkowski J, Delimat A, Turnau K. Arbuscular mycorrhizal and dark septate endophyte colonization along altitudinal gradients in the Tatra Mountains. Arct Antarct Alp Res. 2009;41(2):272-279. http://dx.doi. org/10.1657/1938-4246-41.2.272

32. Trouvelot A, Kough JL, Gianinazzi-Pearson V. Mesure du taux de mycorhization VA d'un systeme radiculaire. Recherche de methodes d'estimation ayant une signification fonctionnelle. In: Gianinazzi-Pearson V, Gianinazzi $S$, editors. Proceedings of the 1st European symposium on mycorrhizae: physiological and genetical aspects of mycorrhizae; 1985 July 1-5; Dijon, France. Paris: Institut National de la Recherche Agronomique; 1986. p. 217-221.

33. Jumpponen A. Dark septate endophytes - are they mycorrhizal? Mycorrhiza. 2001;11:207-211. http://dx.doi. org/10.1007/s005720100112

34. Zubek S, Piątek K, Naks P, Heise W, Wayda M, Mleczko P. Fungal root endophyte colonization of fern and lycophyte species from the Celaque National Park in Honduras. Am Fern J. 2010;100(2):126-136. http://dx.doi. org/10.1640/0002-8444-100.2.126

35. Gerdemann JW, Nicolson TH. Spores of mycorrhizal Endogone species extracted from soil by wet sieving and decanting. Trans Br Mycol Soc. 1963;46(2):235-244. http:// dx.doi.org/10.1016/S0007-1536(63)80079-0
36. Omar MB, Bolland L, Heather WA. A permanent mounting medium for fungi. Bull Br Mycol Soc. 1979;13:13-32.

37. Walker C, Trappe JM. Names and epithets in the Glomales and Endogonales. Mycol Res. 1993;97(3):339-344. http:// dx.doi.org/10.1016/S0953-7562(09)81132-5

38. Lityński T, Jurkowska H, Gorlach E. Analiza chemicznorolnicza. Warszawa: Polish Scientific Publishers PWN; 1968.

39. Kowalkowski A, Król H, Ostrowska A, Sytek S, Szczubiełka Z. Instrukcja laboratoryjna dla pracowni gleboznawczonawożeniowych. Warszawa-Sękocin: Forest Research Institute; 1973.

40. Wang B, Qiu Y-L. Phylogenetic distribution and evolution of mycorrhizas in land plants. Mycorrhiza. 2006;16:299363. http://dx.doi.org/10.1007/s00572-005-0033-6

41. Barroetavena C, Gisler SD, Luoma DL, Meinke RJ. Mycorrhizal status of the endangered species Astragalus applegatei Peck as determined from a soil bioassay. Mycorrhiza. 1998;8:117-119. http://dx.doi.org/10.1007/s005720050222.

42. Turnau K, Haselwandter K. Arbuscular mycorrhizal fungi, an essential component of soil microflora in ecosystem restoration. In: Gianinazzi S, Schűepp H, Barea JM, Haselwandter K, editors. Mycorrhizal technology in agriculture: from genes to bioproducts. Basel: Birkhäuser; 2002. p. 137-149. http://dx.doi.org/10.1007/978-3-0348-8117-3_12

43. Fuchs B, Haselwandter K. Red list plants: colonization by arbuscular mycorrhizal fungi and dark septate endophytes. Mycorrhiza. 2004;14:277-281. http://dx.doi.org/10.1007/ s00572-004-0314-5

44. Zubek S, Turnau K, Błaszkowski J. Arbuscular mycorrhiza of plants from the Mountain Botanical Garden in Zakopane. Acta Mycol. 2005;40:25-41.

45. Zubek S, Turnau K, Tsimilli-Michael M, Strasser RJ. Response of endangered plant species to inoculation with arbuscular mycorrhizal fungi and soil bacteria. Mycorrhiza. 2009;19:113-123. http://dx.doi.org/10.1007/ s00572-008-0209-y

46. Zubek S. Arbuscular mycorrhizal fungi and their biotechnological potential to improve quality and quantity of cultivated medicinal plants. Rośliny Lecznicze w Polsce i na Świecie. 2009;1-2:33-43.

47. McGonigle TP, Fitter AH. Ecological specificity of vesicular-arbuscular mycorrhizal associations. Mycol Res. 1990;94(1):120-122. http://dx.doi.org/10.1016/ S0953-7562(09)81272-0

48. Helgason T, Merryweather JW, Denison J, Wilson P, Young JPW, Fitter AH. Selectivity and functional diversity in arbuscular mycorrhizas of co-occurring fungi and plants from a temperate deciduous woodland. J Ecol. 2002;90(2):371-384.

49. Wubet T, Weiß M, Kottke I, Oberwinkler F. Two threatened coexisting indigenous conifer species in the dry Afromontane forests of Ethiopia are associated with distinct arbuscular mycorrhizal fungal communities. Can J Bot. 2006;84(10):1617-1627. http://dx.doi.org/10.1139/b06-121

50. Cavagnaro TR, Gao L-L, Smith FA, Smith SE. Morphology of arbuscular mycorrhizas is influenced by fungal identity. New Phytol. 2001;151(2):469-475. http://dx.doi.org/10.1046/j.0028-646x.2001.00191.x

51. Yamato M. Morphological types of arbuscular mycorrhizal fungi in roots of weeds on vacant land. Mycorrhiza. 2004;14:127-131. http://dx.doi.org/10.1007/ s00572-003-0246-5 
52. Kubota M, McGonigle TP, Hyakumachi M. Cooccurrence of Arum- and Paris-type morphologies of arbuscular mycorrhizae in cucumber and tomato. Mycorrhiza. 2005;15(2):73-77. http://dx.doi.org/10.1007/ s00572-004-0299-0

53. Dickson S, Smith FA, Smith SE. Structural differences in arbuscular mycorrhizal symbioses: more than 100 years after Gallaud, where next? Mycorrhiza. 2007;17(5):375-393. http://dx.doi.org/10.1007/s00572-007-0130-9

54. Orłowska E, Zubek S, Jurkiewicz A, Szarek-Łukaszewska $\mathrm{G}$, Turnau K. Influence of restoration on arbuscular mycorrhiza of Biscutella laevigata L. (Brassicaceae) and Plantago lanceolata L. (Plantaginaceae) from calamine spoil mounds. Mycorrhiza. 2002;12:153-159.http://dx.doi.org/10.1007/ s00572-001-0155-4

55. Dickson S, Schweiger P, Smith FA, Söderström B, Smith S. Paired arbuscules in the Arum-type arbuscular mycorrhizal symbiosis with Linum usitatissimum. Can J Bot. 2003;81:457-463. http://dx.doi.org/10.1139/b03-037

56. Arbuscular mycorrhizal fungi (Glomeromycota), Endogone and Complexipes species deposited in the Department of Plant Pathology, University of Agriculture in Szczecin, Poland [Internet]. 2010 [cited 2010 May 31]; Available from:
http://www.zor.zut.edu.pl/Glomeromycota/

57. Haselwandter K, Read DJ. The significance of a rootfungus association in two Carex species of high-alpine plant communities. Oecologia. 1982;53:352-354. http:// dx.doi.org/10.1007/BF00389012

58. Zijlstra JD, Van’t Hof P, Braakhekke WG, Berendse F, Baar J, Paradi I, et al. Diversity of symbiotic root endophytes of the Helotiales in ericaceous plants and the grass, Deschampsia flexuosa. Stud Mycol. 2005;53(1):147-162. http://dx.doi. org/10.3114/sim.53.1.147

59. Upson R, Read DJ, Newsham KK. Nitrogen form influences the response of Deschampsia antarctica to dark septate root endophytes. Mycorrhiza. 2009;20:1-11. http://dx.doi. org/10.1007/s00572-009-0260-3

60. Mirek Z, Piękoś-Mirkowa H, Zając A, Zając M. Flowering plants and pteridophytes of Poland - a checklist. Kraków: W. Szafer Institute of Botany, Polish Academy of Sciences; 2002. (Biodiversity of Poland; vol 1).

61. Anioł-Kwiatkowska J. Wielojęzyczny słownik florystyczny. Wrocław: Wrocław University Press; 2003.

62. Gucwa-Przepióra E, Błaszkowski J. Arbuscular mycorrhiza of plants spontaneously colonizing the soda heap in Jaworzno (southern Poland). Acta Soc Bot Pol. 2007;76:69-74. 